\title{
SEJARAH DAN PERUBAHAN PESANTREN DI ACEH
}

\author{
Marzuki \\ STAIN Malikussaleh Lhokseumawe-Aceh \\ Email: marzukiabubakar84@gmail.com
}

\section{Abstract}

Pesantren has a long history, since before independence and still exist today. Zamakhsary Dhofier in his book "Tradisi Pesantren" indicates that the boarding school kept changing his way, reinforced by the statement of HAR Gibb and Snouck Hurgronjo about such changes. Actually what is happening in the development indicated boarding school, both pesantren in Java and outside Java, such as in Aceh. This change has long occurred in Java, even since the Dutch era, but in Aceh, the change has just occurred in recent years. Pesantren has transformed himself from the agency / institution that had shaped Meunasah (musalla), balee (hall) which traditionally becomes a nuanced Madrasah education by adopting modern, up to recent developments in Higher Education has been established in the pesantren.

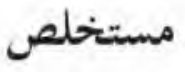

كان المعهد الإسلامي في إندونسيا مو جرودا قبل استقلال إندونيسيا وله مكان عالي في

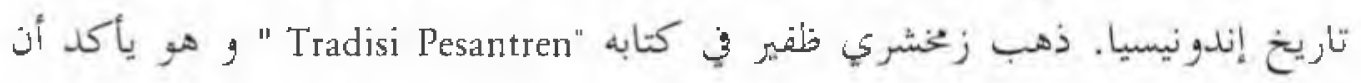

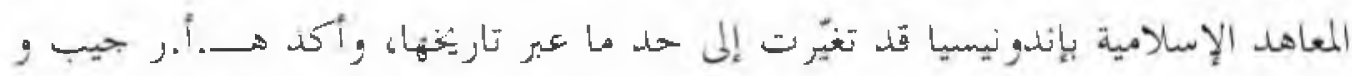

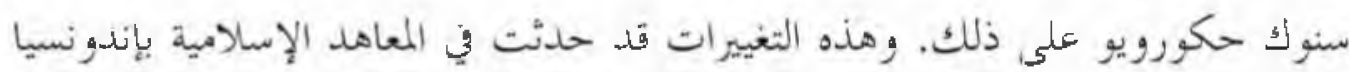

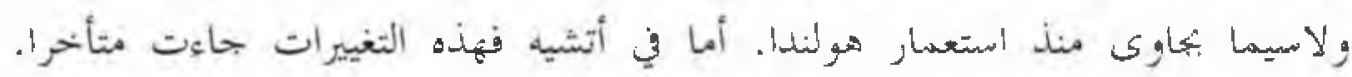

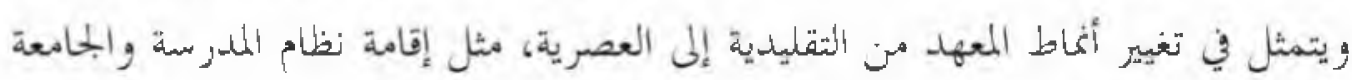
في المعاهد الإسلامية.

Keywords: Pesantren, Sejarah, Aceh 


\section{A. Pendahuluan}

Dayah (bahasa Aceh) adalah nama lembaga yang dikenal dengan sebutan pesantren di Jawa atau surau di Padang atau pondok di Thailand. Kata Dayah ini berasal dari bahasa Arab "zawiyah". ${ }^{1}$ Istilah zawiyah, secara literal bermakna sudut, yang diyakini oleh masyarakat Aceh pertama sekali digunakan sudut mesjid Medinah ketika Nabi memberi pelajaran kepada para shahabat di awal Islam. ${ }^{2}$ Orang-orang ini, sahabat Nabi kemudian menyebarkan Islam ke tempattempat lain.

Pada abad pertengahan, kata zawiyah dipahami sebagai pusat agama dan kehidupan sufi yang kebiasaannya menghabiskan waktu di perantauan. Kadangkadang lembaga ini dibangun menjadi sekolah agama dan pada waktu-waktu tertentu juga zawiyah dijadikan sebagai pondok bagi pencari kehidupan spiritual. ${ }^{3}$ Dari ilustrasi ini dapat dipahami nama ini juga kemudian sampai ke Aceh. Dalam bahasa Aceh zawiyah itu akhirnya berubah menjadi Dayah karena dipengaruhi oleh bahasa Aceh yang pada dasarnya tidak memiliki bunyi " $Z$ ” dan cendrung memendekkan. ${ }^{4}$

Dayah di Aceh merupakan lembaga pendidikan tradisional Islam yang bertujuan untuk membimbing anak didik (Aneuk Dayah, santri) untuk menjadi manusia yang berkepribadian islami, yang sanggup menjadi umat yang berguna bagi bangsa dan negara serta agama. Diharapkan dari Dayah lahir insan-insan yang menekankan pentingnya penerapan akhlak agama Islam yang merupakan pedoman hidup bermasyarakat sehari-hari. Bila ditinjau dari sudut historis kultural, Dayah di Aceh dapat dikatakan sebagai pusat pelatihan yang secara otomatis menjadi pusat budaya Islam yang disahkan atau dilembagakan oleh masyarakat di Aceh.

Dayah-Dayah di Aceh dapat dikatakan sebagai "bapak" dari pendidikan Islam yang didirikan berdasarkan tuntutan dan kebutuhan zaman, yang mana Dayah dilahirkan atas kesadaran kewajiban islamiah, yaitu menyebarkan dan mengembangkan agama Islam, sekaligus mencetak kader-kader ulama dan da’i. hal. 63.

1 C. Snouck Hurgronje, The Atjehnese, A.W.S.O'Sullivan (terj), Vol.I, (Leiden: E.J.Brill, 1906),

2 Tgk. Mohd Basyah Haspy, Apresiasi terhadap Tradisi Dayah: Suatu Tinjauan Terhadap Tata Krama dan Kehidupan Dayah, (Banda Aceh: Panitia Seminar Appresiasi Pesantren di Aceh, Persatuan Dayah Inshafuddin, 1987), hal. 7.

3 Tgk. Mohd Basyah Haspy, Ibid.,hal. 9.

4 Badruzzaman Ismail,dkk (ed), Perkembangan Pendiidkan di Nanggroe Aceh Darussalami, (Banda aceh:Majlis Pendidikan Daerah Aceh, 2002), hal. 61. 
Tidak sedikit ulama-ulama Dayah yang terkenal, baik dari segi keilmuannya juga dari sumbangsihnya kepada negara. Banyak ulama-ulama Aceh yang syahid, gugur di medan perang melawan penjajah, membela negara dan tanah air, seperti Teungku Chik Di Tiro, Teungku Chik Kuta Karang, Teungku Fakinah dan seumpama beliau. Mereka ini adalah insan pilihan yang merupakan hasil dari didikan Dayah.

Sekarang Dayah telah berkembang pesat di Aceh, dari berbagai jenis. Dayah salafiyah (tradisional) masih bertahan dengan sistem pendidikan yang diwariskan turun-temurun dari satu generasi ke generasi. Kebanyakan dari Dayah tradisional masih dikelola oleh seorang pimpinan Dayah yang bila sudah wafat kemudian digantikan oleh pimpinan yang lain setelahnya, biasanya digantikan oleh anakanak dari pimpinan Dayah tersebut, atau juga dapat digantikan oleh menantu dan mungkin juga kerabat yang lain. Ini dikarenakan Dayah tradisional di Aceh kebanyakannya milik pribadi seseorang pimpinan Dayah atau milik orang lain yang dikelola oleh seorang Teungku Chik atau $A b u$ pimpinan Dayah.

Keberadaan Dayah yang telah berabad-abad, menjadi fenomena yang menarik, sebagai lembaga pendidikan Islam yang tertua di Indonesia, khususnya di Aceh Dayah memiliki sejarah dan lika-liku yang bereda. Keberadaan Pesantren di Jawa sudah banyak diteliti dan diamati oleh para ilmuan baik dari dalam maupun luar negeri, seperti Manfred Ziemek, Zamakhsyari Dhofier dan Mujamil Qamar. Ternyata pesantren-pesantren di Jawa telah mengalami perubahan (change). Oleh karena itu sangat menarik untuk dilihat bagaimana sejarah Dayah sebagai sebuah lembaga pendidikan tertua di Indonesia? apakah Dayah telah mengalami perubahan? serta bagaimana perubahan tersebut terjadi?

Dalam tulisan ini, penulis menggunakan sebutan Dayah untuk pesantren, karena istilah ini sangat akrab dalam masyarakat Aceh, serta dalam beberapa referensi yang penulis gunakan cendrung digunakan istilah Dayah dalam pembahasannya.

\section{B. Teori H.A.R. Gibb dan Snouck Hurgronjo}

Menurut H.A.R. Gibb, Tidak ada satu pun aliran-aliran dalam filsafat dan agama yang betul-betul mandeg selama enam abad. Ia berpendirian seperti ini karena mengutip pernyataan Snouck Hurgronjo:

"Islam di Jawa yang kelihatannya demikian statis dan demikian kuat terbelenggu oleh pikiran-pikiran "ulama" di abad pertengahan, sebenarnya telah mengalami perubahan-perubahan yang fundamental; tetapi perubahan-perubahan tersebut 
demikian bertahap-tahap, demikian rumit dan demikian dalam tersimpan. Itulah sebabnya bagi para pengamat yang tidak kenal dengan pola pikiran Islam, maka perubahan-perubahan tersebut tidak akan bisa terlihat, walaupun sebenarnya terjadi di depan matanya sendiri, kecuali bagi mereka yang mengamatinya secara seksama". ${ }^{5}$

Di Indonesia, Pesantren mempunyai peran yang cukup besar dalam perjuangan kemerdekaan, setelah kemerdekaan dan bahkan sekarang Pesantren masih eksis menghasilkan para ulama yang cerdas dan banyak dari mereka yang sudah menjadi petinggi-petinggi negara, legislatif maupun esekutif. Walaupun masih dipandang sebagai sebuah lembaga yang tradisionalis, pesantren telah banyak mengalami perubahan, baik dari segi kelilmuan maupun kehidupan.

Tradisi pesantren merupakan kerangka sistem pendidikan Islam tradisional di Jawa dan Madura,yang dalam perjalanan sejarahnya telah menjadi objek penelitian para sarjana yang mempelajari Islam di Indonesia. Walaupun demikian, hanya sedikit yang mereka ketahui tentang pesantren. Para sarjana seperti Van den Berg, S. Houronjo dan Geertz yang sudah mengakui adanya pengaruh kuat dari pesantren dalam membentuk dan memelihara kehidupan sosial, kultural, politik dan keagamaan orang-rang Jawa di pedesaan, mengetahui hanya sebagian kecil saja dari ciri-ciri pesantren.

Beberapa kumpulan karangan tentang pesantren yang ditulis oleh sekelompok intelektual Islam Indonesi turut membantu menambah pengetahuan kita tentang pesantren, tetapi karangan-karangan ini belum membahas pesantren dalam kaitannya dengan sejarah dan perubahan yang terjadi dalam pesantren di Aceh.

\section{Pola Umum Pendidikan Islam Tradisional}

Umumnya, pendidikan agama secara tradisional untuk pemula, diselenggarakan di rumah guru-guru ngaji di langgar, atau masjid. Selanjutnya pengajaran itu diselenggarakan oleh lembaga-lembaga. Semua lembaga pengajian tida sam jenisnya; lembaga tersebut bertingkat-tingkat. Bentuk yang paling rendah bermula pada anakanak kira-kira 5 tahun, mnerima pelajaran dari orang tuanya menghafalkan beberpa surat pendek dari juz Al-Qur'an yang terakhir. Setelah mereka berumur 7 atau 8 tahun mulai diajarkan membaca alfabet Arab dan secara bertahap diajar untuk dapat memaca Qur'an. pelajaran biasanya diberikan setelah magrib.

Zamaksyari Dhofir, Tradisi Pesantren, Studi tentang Pandangan Hidup Kiyai, (Jakarta: LP3ES, 1984), hal. 2 
Program pengajaran ini biasanya berhenti setelah seorang anak dapat membaca Qur'an tersebut dengan lancar dan benar. Setelah itu mereka melanjutkan pelajaran untuk dapat membaca dan menterjemahkan buku-buku Islam klasik yang elementer yang ditulis dalm bahasa Arab. Setelah itu mereka memperdalam bahasa Arab untuk dapat memperdalam buku-buku tentang fiqh, ushul fiqh, hadits, adab, tafsir, sejarah, tasawuf dan akhlak. Ini dapat mereka peroleh di Dayah-Dayah. Untuk masa sekarang mereka dapat memperolehnya juga di IAIN dan STAIN.

\section{Pendidikan Dayah Sebelum Perang}

Masyarakat Aceh sekarang ini sedikit sekali mengetahui tentang keadaan pendidikan Dayah di Aceh sebelum perang Aceh pada tahun 1873. Hal ini disebabkan karena perang Belanda di Aceh tersebut telah mengahambat dan merusak sistem pendidikan Dayah di Aceh, dan sesudah Belanda berkuasa, mereka membangaun sistem pendidikan barat di Aceh. Sistem pendidikan di Aceh pada masa itu meliputi pendidikan di meunasah-meunasah, rangkang, Dayah Tengku Chik, sampai pendidikan pada al-Jamiah seperti Masjid Raya Baiturrahman Banda Aceh. Adanya lembaga-lembaga pendidikan seperti ini sebelum perang Aceh dapat dilihat pada berbagai situs peniggalan sejarah yang banyak sekali dari lembaga tersebut, diantaranya Dayah Teungku Awe Geutah di Peusangan, Dayah Teungku Chik di Tiro ( Syekh Saman), Dayah Teungku Chik Tanoh Abee di Seulimum, Dayah Teungku di Lamnyong, Dayah Lambhuek dan Dayah di Krueng Kalee.

Salah satu sumber tertulis yang sampai kepada kita tentang pendiidkan di Aceh sebelum perang adalah Hikayat Pocut Muhammad karya salah seorang ulama dan sastrawan yang diduga Tengku Lam Rukam. Hikayat tersebut sudah diterjemahkan dalam bahasa Inggris oleh W. G. J. Drewes, seorang orientalis Belanda pada tahun 1979. Pada halaman 143, berkenaan dengan pendidikan di Aceh ia menulis sebagai berikut:

1160: Oh saree troh bak meunasah, geutamong leupaih sigra-sigra

Murid teungku na nam reutoih, Saree reuyoh subra donya

$\mathrm{Na}$ yang ladom beuet kuruan ladum tuan masaila

Ladom dibeuet jeurumiah, jipinah matan fatihah

Ladom jibeuet kitab jawoe, ladom laloe bak poh cakra

1165: Rangkang ret barat ureung beuet nahu, rangkang ret timu ureung meuhija

Rangkang ret tunong ureung beuet tasawof, ilime haloh hikam eheuya.

Meunan-meunan ban yang babat, ladom arab ladom jawa

Di teungku maung neupeutimang,jeut-jeut rangka waineu na

Teungku wako tundok ulee, neu eu lage ureung meuhija. 
Berikut terjemahan dari Hikayat Potjut Muhammad: Edisi G.W.J. Drewes, 1979, halaman134:

Murid teungku ada enam ratus, begitu hiruk pikuk suara gemuruh. Ada yang membaca al-Quran, sebagian lain membaca kitab masail.

Sebagaian mempelajari kitab jurumiah, sebagian lain surat al-Fatihah.

Sebaian belajar kitab jawo (bahasa Melayu dengan aksara Arab), sebagian asyik berbualbual.

Di pondok di sisi bagian barat orang belajar Tata Bahasa Arab

Dipondok di sisi bagian timur orang belajar mengeja.

Dipondok di sisi bagian selatan orang belajar tasawuf, ilmu pengetahuan Hikam, Ihya ulumuddin.

Begitulah kapasitas masing-masing, sebagian belajar dalam Bahasa Arab sebagian lain masih dalam bahasa Jawo. Teungku mengamati pengajian, tiap pondok ada pembantunya. Pembantu menundukkan kepala memperhatikan moerid-murid mengeja.

Dari syair di atas dapat diketahui betapa profil pesantren yang di Aceh sendiri lebih dikebal denga kata Dayah (transletelasi dari kata zawiyah). Unsur penting yang membentuk Dayah adalah ulama (teungku), siswa (murib), pondok (rangkang) balai dan kitab-kitab klasik karangan ulama-ulama bermazhab Syafie (kitab kuneng). ${ }^{6}$

Selain Hikayah Pocut Muhammad, sejarah juga mencatat bahwa ulama-ulama yang menjadi pimpinan Dayah, banyak yang datang dari luar negeri dan menetap di Aceh dalam berbagai lembaga pendidikan Dayah, serta ulama Aceh sendiri merupakan ulama besar yang banyak pengalaman akademis, sehingga dapat dikatakan pendidikan Dayah di Aceh sebelum perang sangat metropolitan.

\section{Pendidikan Dayah di Masa Perjuangan}

Sifat metropolitan dari pendidikan Dayah pada masa kesultanan (sebelum perang), merupakan faktor penting bagi kesinambungan tradisi pendidikan di Aceh pada masa kekuasaan Belanda, yang dimaksud dengan konsep metropolitan di sini adalah bahwa pendidikan Dayah itu tidak tergantung pada sumber daya lokal saja dan tradisi itu tidak bersifat eklusif. Disebabkan pendidikan Dayah di Aceh tidak berdiri sendiri, maka dalam perangpun pendidkan itu dapat dipertahankan denga hijrah ulama-ulama untuk terus mengembagnkan tradisi pendidikan Dayah di tempat lain yang tidak terjangkau oleh perang.

6 M. Isa Sulaiman, Sejarah Aceh, (Jakarta: Pustaka Sinar Harapan, 1997). hal. 31-32. 
Pada masa kolonial Belanda, setiap Daerah (nanggroe) memiliki sekurangkurangnya sebuah Dayah. Penjajah Belanda kemudian mengubah nanggroe menjadi landschap yang jumlahnya 129 buah. Dengan demikian, jumlah Dayah diperkirakan setidak-tidaknya ada 129 buah.

Nampaknya selama perang kolonial Belanda, Dayah memegang peranan penting dalam pengerahan tenaga pejuang (murid) ke medan pertempuran maupun dalam menumbuhkan semangat juang rakyat secara massal, terutama melalui pembacaan hikayat perang sabi di Dayah-Dayah, rangkang, meunasah dan masjid. Bahkan ada Dayah, seperti Dayah di sekitar Batee Iliek yang langsung menjadi kota pertahanan (kuta pertahanan). Karena itu tidak mengherankan selama abad ke-19 banyak Dayah yang terbengkalai atau langsung diserang oleh Belanda karena dianggap sebagai basis konsentrasi kekuatan pejuang rakyat. ${ }^{7}$ Setelah perang rakyat semesta terhenti (lebih kurang tahun 1904) perlawanan secara berkelirya terus berlangsung sampai Belanda meninggalkan Indonesia. Barulah para ulama (Teungku Chik) berusaha membangun kembali Dayah-Dayah di rangkang yang selama ini ditinggalkan. Agaknya, sejak waktu itu istilah Dayah atau rangkang kadang-kadang dipergunakan juga seperti yang diistilahkan di Pulau jawa, yaitu pesantren. Bahkan, di Aceh Barat dan Selatan istilah ini lebih populer dibandingkan dengan Dayah dan rangkang.

Pada permulaan pendudukan militer Jepang tahun 1942, di Aceh Selatan didirikan sebuah Pesantren yang sampai sekarang terkenal dan induk dari pendidikan Dayah di seluruh Aceh, yaitu Pesantren Darussalam Labuhan Haji. ${ }^{8}$

\section{Pendidikan Dayah di Era Kemerdekaan}

Perkembangan pendidikan sejak kemerdekaan belum lagi berubah dari pola lokalisasi yang dialami sejak abad ke-20. Pada masa awal kemerdekaan, Dayah Darussalam Labuhan Haji tetap menjadi sumber kader pemimpin Dayah sebagaimana tersebut di atas. Sehubungan dengan berkembangnya pendidikan sekolah dan madrasah dalam zaman kemerdekaan ini, pendidikan Dayah yang bersifat swasta penuh menjadi sangat tersaingi oleh kedua lembaga tersebut. Disamping itu sifat dari pendidikan Dayah yang dimiliki secara individual oleh ulama dirasakan agak sulit dalam pembinaan secara terorganisir. Mungkin karena faktor-faktor inilah akhirnya ulama dan pimpinan Dayah di seluruh Aceh berkumpul

7 Rusdi Sufi dan Agus Budi Wibowo, Pendidikan di Aceh dari Masa ke Masa, (Banda Aceh: Badan Arsip dan Perpustakaan NAD, 2009), hal. 44.

8 Rusdi Sufi dan Agus Budi Wibowo, Ibid,.hal. 45. 
di Seulimeum Aceh Besar pada tahun 1968, dan mendirikan organisasi Persatuan Dayah Insafuddin, sebagai suatu organisasi yang bergerak dalam melestarikan dan mengembangkan pendidikan Dayah di Aceh.

\section{Dayah Pada Masa Sekarang}

Setelah Teungku Haji Mudi Wali Al-Khalidy meninggal dunia dan Dayahnya menjadi mundur, posisi pembinaan kader ini nampaknya beralih ke Dayah Ma'hadul 'Ulum Diniyah Islamiyah Masjid Raya (MUDI MESRA) Samalanga, Bireun, terutama di bawah pimpinan Teungku Abdul Aziz Shaleh'. Bahkan setelah meninggalnya Teungku Abdul Aziz Shaleh, MUDI Mesra di bawah pimpinan Teungku H. Hasnoel Bashry, semakin hari semakin bertambah berkembang pesat seiring perkembangan zaman. Selain itu jumlah santri yang mengenyam pendidikan agama Islam di pesantren itu menjadi lebih banyak.

Walaupun demikian, Dayah Darussalam Labuhan Haji masih eksis sampai sekarang. Ciri khas dari Dayah ini adalah adanya pengamalan Thariqat. Semua santri wajib mengamalkan thariqat bila telah dianggap matang untuk menerima thariqat. Thariqat yang berkembang di sini adalah Naqsyabandiyah, salah satu Thariqat yang cukup masyhur dan kebanyakan diamalkan oleh masyarakat Aceh sampai sekarang. Setelah Abuya Muda Wali wafat, penyebaran Thariqat ini dilakukan oleh murid-muridnya seperti Abu Lueng Ie (Abu Usman al-Fauzi) Aceh Besar, Abu Tumin di Bireun, Abu Aziz Samalanga, Abu Tanoh Mirah dan juga beberapa anak beliau, seperti Abuya Doktor (Abu Muhibbudin Wali), Abu Amran Wali, Abu Nasir Wali (alm), Abuya Jamaluddin Wali, Abu Abdurrauf yang sekarang pimpinan Dayah Darussalam.

Beberapa Dayah besar sekarang didirikan oleh para alumni dari Dayah Darussalam Labuhan Haji. Misalnya, Dayah Mudi Mesra Samalanga, Dayah Tanoh Mirah, Dayah Abu Tumin Blang Bladeh, dan lain-lain.

Secara umum pendidikan ilmu agama Islam di Aceh sangat dipengaruhi oleh keberadaan Dayah. Di setiap gampong (desa) terdapat Dayah kecil (rangkang) atau balee (balai) untuk pengajian atau minimal dalam satu kemukiman terdapat satu Dayah. Pada masa modern pendidikan Dayah tetap bertahan dan eksis sebagai tempat pendidikan ilmu agama Islam. Namun demikian, perkembangan zaman tetap mempengaruhi keberadaan Dayah yang menuntut Dayah harus ikut menyesuaikan diri dengan kemajuan zaman, tidak justru mengalah atau mundur.

9 Badruzzaman Ismail,dkk (ed), Perkembangan .....hal. 64.). 
Terdapat dua model pengaruh yang disebabkan oleh perkembangan zaman (mordernitas) ini. Pertama, bagi mereka yang menjadikan pendidikan Dayah sebagai dasar pendidikan, Dayah memiliki perananan yang sangat penting dalam kehidupan seseorang. Setiap anak diwajibkan belajar dengan pendidikan pesantren, kemudian diikuti oleh pendidikan umum yaitu sekolah, baik MA (Madrasah Aliyah) atau SMA (sekolah Menengah Atas). Sudah menjadi kebiasaan bagi setiap anak dalam masyarakat Aceh, pertama sekali diharuskan belajar di meunasah (surau), biasanya mereka belajar shalat dan ibadah-ibadah lain serta baca tulis al-Quran dan kitabkitab jawi seperti Masailal muhtadi. Kemudian setelah mendapatkan izin dari Teungku (ustaz) dengan sekira-kira dia sudah lulus, barulah dia dapat melanjutkan ke jenjang Dayah. Di Dayah biasanya proses pembelajaran langsung menggunakan kitab-kitab arab (kitab kuning). Setelah mereka belajar di Dayah, mereka menerima ijazah setingkat Aliyah untuk melanjutkan pendidikan di STAI atau IAIN.

Model kedua, yang menjadikan pendidikan pesantren dan sekolah sebagai dasar pendidikan bagi seseorang, pesantren dan sekolah memiliki peranan yang sama dalam pembangunan anak manusia. Anak-anak diberikan pendidikan sekolah dari SD sampai dengan tingkat SMA/MA, dan disamping itu mereka tetap belajar di meunasah-meunasah atau surau pada sore atau malam hari (Pendidikan di meunasah-meunasah ini seperti sekarang sudah diganti dengan pendidikan TPA, Taman Pendidikan al-Quran). Setelah mereka tamat belajar di meunasah, mereka melanjutkan pendidikan agama Islam di Dayah. Mereka belajar pada malam dan subuh hari. Malam hari pembelajaran dimulai dari setelah magrib sekitar pukul 08.30 WIB sampai dengan pukul 10.00 WIB. Para santri ini menginap di komplek Dayah. Biasanya di Dayah-Dayah terdapat beberapa kamar berbentuk asrama (bilek). Pagi hari pembelajaran dimulai setelah subuh sampai dengan pukul 07.00 WIB, setelah itu para santri pulang ke rumah mereka masing-masing dan seterusnya bersiapsiap untuk berangkat sekolah.

IAIN dan STAI dari dulu sudah banyak menerima mahasiswa yang berijazah Dayah yang setingkat Aliyah, Dayah mengeluarkan ijazah bagi para santri yang telah berhasil duduk sampai ke tingkat kelas tujuh (kelas akhir di Dayah).

Kemudian dalam perkembangan selanjutnya muncul model pendidikan pesantren terpadu yang mengeluarkan dua ijazah, yaitu ijazah SMA/Aliyah dan ijazah Pesantren setingkat Aliyah. Para santri dapat menggunakan salah satu dari ijazah tersebut untuk masuk ke IAIN atau STAI, dan bisa juga mereka menggunakan ijazah umum sederajat SMA untuk masuk perguruan tinggi umum, seperti Unsyiah dan universitas-universitas lainnya. 


\section{Perubahan-Perubahan dalam Pesantren di Aceh}

Sejak sebelum kemerdekaan, Dayah telah memiliki peranan yang sangat penting dalam mengembangkan dan meneruskan pendidikan Islam di Indonesia. Terbukti dari banyaknya para pejuang dan ulama yang telah dilahirkan oleh Dayah, mereka sebagian besar adalah para Pahlawan Nasional. Selain itu eksistensi Dayah yang masih bertahan sampai sekarang menunjukkan bahwa Dayah memiliki peranan dan manfaat yang besar dalam masyarakat.

Seterusnya Dayah mengalami perpecahan dari bentuk aslinya menjadi beberapa lembaga pendidikan Islam terpadu dan Modern. Dayah-Dayah ini resmi membuka madrasah dan sekolah Islam. Tetapi Dayah tradisional (salafiah) masih mempunyai tempat tersendiri di masyarakat Aceh. Sehingga Dayah di Aceh masih sangat identik dengan lembaga pendidikan tradisional. Walaupun demikian, Dayah memiliki komitmen yang tinggi dalam memajukan pendidikan Aceh, ini dibuktikan oleh Dayah MUDI Mesra Samalanga. Pada tahun 2004, Dayah ini resmi membuku Perguruan Tinggi, yaitu Sekolah Tinggi Agama Islam (STAI) Aziziyah. STAI ini menerima mahasiswa dari para santri yang telah menamatkan belajar di Dayah tersebut. Walaupun ada sebagian yang telah memiliki ijazah Aliyah dari MA (madrasah aliyah).

Sejak lama Dayah telah mulai mengalami perubahan-perubahan baik secara fisik maupun non fisik. Perubahan fisik yang jelas nampak antara lain: Pertama, bentuk bangunan, yaitu telah menadopsi gaya modern untuk bangunan-bangunan di lingkungan Dayah, disamping bangunan asli yang terdiri dari balai-balai (balee), selain itu sebagaian dayah sudah mulai menyediakan ruang-ruang belajar dan papan tulis seperti di sekolah umum, begitu juga ruang perkantoran, koperasi dan aula serta asrama yang dulunya berbentuk kamar (bilek) yang terkesan kumuh dan kotor, kini telah diganti dengan gedung asrama yang bernuansa modern. ${ }^{10}$

Kedua, telah tersedianya fasilitas-fasilitas umum, seperti sarana olahraga, perpustakaan, dan kantin, sarana seperti ini tidak dimiliki oleh Dayah-Dayah di Aceh pada umumnya, karena sebagian menganggap olahraga hanya hura-hura dan tidak ada manfaatnya. Begitu juga perpustakaan, dulunya sama sekali di Dayah tidak ada perpustakaan, santri memiliki kitab sendiri untuk belajar sesuai kelas yang ia duduki. Disamping telah tumbuhnya kesadaran dan keterbukaan wawasan

${ }^{10}$ Di sebagian Dayah juga terdapat kamar-kamar santri yang dibuat seerti gubuk yang dibuat sendiri oleh para santri yang belajar (Aceh: meudagang) di dayah tersebut. 
dari ulama atau para pimpinan Dayah, munculnya perpustakaan tidak terlepas dari peranan Bandan Dayah Pemerintah Aceh yang membantu menyediakan kitabkitab dan buku-buku perpustakaan di Dayah-Dayah.

Perubahan non fisik antara lain; Pertama, menggunakan kurikulum, karena model pembelajaran di Dayah dilakukan secara turun temurun, maka kurikulum tidak menjadi suatu hal yang esensial bagi para pengurus atau pimpinan Dayah. Walaupun demikian, pelajaran-pelajaran yang diajarkan di Dayah teutama kitabkitab kuning yang diajarkan telah ditentukan menurut kelas, dari kelas satu sampai dengan kelas tujuh. Kedua, telah memiliki manajemen baik dalam bidang akademik maupun keuangan. Dalam bidang akademik misalnya adanya jadwal ujian dalam setahun, dan kemudian diberi Buku Rapor hasil ujian. Bagi siswa yang berprestasi akan mendapatkan penghargaan dan hadiah. Di sebagian Dayah, biasanya juga diadakan sayembara (musabaqah) pada tiap akhir tahun. Materi yang diperlombakan biasanya adalah baca kitab kuning, pidato, dalail khairat, dan cerdas cermat (fahmil kutub). Dalam bidang keuangan, dayah juga memiliki bendahara umum dan bendahara kelas. Bendahara umum memegang kas dayah dan bertanggungjawab langsung kepada pimpinan. Sedangkan bendahara kelas hanya sebagai pemegang kas kelas. Dalam membenahi manajemen ini, Pemerintah Aceh melalui Badan Dayah sering mengadakan pelatihan untuk menertibkan administrasi Dayah-Dayah di Aceh.

Ketiga, adanya pelajaran-pelajaran tambahan (ektrakurikuler) bagi santri. Diantara kegiatan ekstrakurikuler yang ada di Dayah saat ini adalah berbicara belajar bahasa Arab (muhadastah) dan Inggris (speaking), belajar menulis, berceramah dan menjahit (kusus bagi santriwati).

Keempat, penyelenggaraan sekolah umum setingkat Tsanawiyah dan 'Aliyah serta Sekolah Tinggi Agama Islam di Lingkungan Dayah. Beberapa Dayah telah menyelenggarakan sekolah setingkat Tsanawiyah dan Aliyah dan bahkan banyak diantaranya telah mengadopsi model Pesantren terpadu. Tetapi untuk Dayah yang membuka perguruaan Tinggi hanya Pesantren Ma'had Ulum ad-Diniyah Masjid Raya Samalanga (MUDI-Mesra).

Nampaknya telah muncul sebuah iklim baru pendidikan di Aceh, sejak Dayah Mudi Mesra melalui Yayasan Pendidikan Islam Al-Aziziyah mendirikan Sekolah Tinggi Agama Islam (STAI) Al-Aziziyah. Sebuah langkah perubahan yang sangat berani dalam kalangan ulama Dayah. Langkah ini mendapat sanggahan yang luar biasa dari para ulama Dayah yang lain yang keberatan. Karena sebelumnya belum 
pernah ada Dayah yang membuka pendidikan Islam modern seperti ini. Para ulama sebelumnya belum pernah melakukan hal ini mungkin ditakutkan dapat menghilangkan ciri khas Dayah itu sendiri.

Namun kekhawatiran tersebut sepertinya hampir tidak terjadi, dengan model pendidikan yang dijalankan sekarang, Dayah MUDI Mesra Samalanga masih bercirikan khas Dayah yang dipadu dengan pendidikan modern. Ini adalah sebuah pemandangan baru di Aceh, walaupun hal ini telah lama dilakukan oleh ulamaulama pesantren di Jawa, bahkan jauh lebih awal pada masa setelah kemerdekaan. Seperti pesantren Tubu Ireng yang didirikan oleh KH. Hasyim As'ary di Jawa Timur.

Para Alumni STAI Aziziyah yang berprestasi telah dipersiapkan untuk menjadi Dosen nantinya, mereka beasiswa untuk melanjutan S2. Mereka yang dipilih adalah yang dipercaya untuk melanjutkan estafet Dayah Tradisional yang bernuansa modern tersebut.

Di samping itu, Hadirnya Badan Dayah ${ }^{11}$ di Aceh menjadi salah satu bukti keseriusan tekat Pemerintah Aceh untuk mengembangkan pendidikan Dayah. Badan ini telah membantu Dayah dalam pengembangan sumberdaya manusia dengan memberikan subsidi dan pelatihan yang berhubungan dengan menajemen pengembangan Dayah di Aceh. ${ }^{12}$

Selain pengembangan secara kuantitas, Dayah juga telah mengembangkan diri secara kualitas, melakukan perubahan-perubahan dalam upaya meningkatkan kompetensi keilmuan dan ketrampilan, agar dapat bersaing di tingkat nasional maupun internasional.

Para alumni Dayah telah banyak yang melanjutkan pendidikannya di Perguruan Tinggi, baik di tingkat sarjana maupun pascasarjana, dengan bantuan pemerintah Aceh. Pemerintah mulai merekrut para alumni yang berprestasi untuk diberikan beasiswa pendidikan.

Sekarang ini sudah banyak alumni Dayah yang menempuh pendidikan tingkat perguruan tinggi di IAIN dan STAIN/STAI. Para alumni kebanyakan bekerja sebagai guru, dosen, pengacara, penghulu dan penyuluh. Pada tingkat mahasiswa para alumni Dayah telah membentuk organisasi alumni Dayah, IMADA (Ikatan Mahasiswa Alumni Dayah). Pada tingkat ulama dibentuk HUDA (Himpunan Ulama Dayah Aceh). Kedua organisasi ini memiliki peranan yang sangat penting bagi alumni Dayah.

11 Sebuah Badan setingkat Dinas yang bertanggung jawab langsung kepaada Gubernur, yang mengurusi bidang Dayah/Pesantren di Aceh.

12 Majelis Pendidikan Daerah Aceh, Refleksi Setengah Abad Pendidikan Aceh, (Banda Aceh: 2010), hal 30. 
Perubahan-perubahan yang terjadi di Dayah disebabkan oleh dua faktor utama, yaitu pertama, tuntutan masyarakat atau dunia kerja, sebagai negara sedang berkembang tentunya masyarakat Indonesia sedang mengalami perkembangan ke arah masyarakat modern. Oleh karena itu, keberadaan Dayah sebagai salah satu bagian dari masyarakat dan keberadanya karena didukung oleh masyarakat, maka Dayah dituntut untuk menyesuaikan diri dengan perkembangan zaman, dengan tetap mempertahankan ciri khas pendidikan Dayah sendiri. Para alumni Dayah diharapkan dapat bekiprah dan bersaing dalam dunia kerja serta ikut berpartisipasi dalam membangun masyarakat.

Kedua, Modernisasi dan Globalisasi, arus modernisasi dan globalisasi sangat mempengaruhi para pimpinan Dayah dalam mengorganisasikan Dayah. Keterbukaan dan kebebasan informasi menjadikan para pimpinan Dayah lebih elastis dalam mengelola lembaga pendidikn Islam tersebut. Para pimpinan Dayah biasanya adalah alumni dari beberapa Dayah lain di Aceh yang kemudian telah memilki kecakapan, telah menamatkan belajar dan juga telah mengabdi sebagai guru di tempat ia belajar. Oleh karena itu para pimpinan Dayah ini mendirikan Dayah sesuai dengan Dayah almamaternya. Dalam beberapa dekade terakhir, dikarenakan banyak para alumni Dayah yang melanjutkan pendidikannya di Perguruan Tinggi di IAIN, STAIN dan STAI, setelah lulus dan menjadi sarjana mereka mendidrikan Dayah yang lebih modern dengan perubahan-peruahan yang telah disebutkan, dan kemudian diikuti sedikit demi sedikit oleh Dayah-Dayah lain. Jadi.

\section{E. Penutup}

Dayah memiliki sejarah yang panjang, sejak sebelum kemerdekaan dan masih eksis sampai sekarang. Dayah memiliki peranan yang penting pada masa perang Aceh melawan Belanda. Pada masa ini Dayah merupakan tempat pendidikan, latihan dan barak bagi para pejuang. Begitu juga setelah kemerdekaan, Dayah menjadi referensi utama pendidikan Islam. Banyak para pemimpin yang muncul dan meminpin Aceh kemudian merupakan alumni Dayah, saat ini Dayah juga menjadi sebuah lembaga pendidikan Islam yang sangat berperan dalam masyarakat Aceh. Dayah masih menjadi sumber utama dalam pendidikan Islam.

Selintas Dayah masih dalam bentuknya yang tradisional, tetapi sejak lama Dayah telah mulai mengalami perubahan-perubahan baik secara fisik maupun non fisik. Perubahan fisik yang jelas nampak antara lain: bangunan-bangunan dalam pesantren yang berbentuk sekolah, kamar (bilek) telah diubah dalam bentuk asrama- 
asrama, tersedianya fasilitas-fasilitas olahraga, perpustakaan, kantor, dan kantin. Perubahan non fisik antara lain; adanya kurikulum, manajemen akademik, administrasi dan keuangan, ekstrakulrikuler seperti belajar berbicara bahasa Arab (muhadatsah) dan Inggris (speaking), belajar menulis, berceramah, dan menjahit kusus bagi santriwati, serta telah diselenggarakannya sekolah umum setingkat Tsanawiyah dan 'Aliyah, dan Sekolah Tinggi Agama Islam di Lingkungan Dayah.

Dengan demikian, apa yang diindikasikan oleh H.R Gibb dan Snouck Hurgronje benar-benar telah terjadi, perubahan-perubahan yang terjadi sangat halus dan pelan. Perubahan-perubahan ini disebabkan oleh beberapa faktor antara lain; Tuntutan masyarakat atau dunia kerja, pengaruh modernisasi dan globalisasi. Hal ini juga jelas terlihat dalam Pesantren-Pesantren di Jawa dan Pesantren (Dayah) di Aceh. Walaupun di Aceh baru terlihat secara jelas dalam beberapa tahun terakhir, setelah abad ke-21, dan puncaknya pada tahun 2004, ketika salah satu Dayah besar dan masyhur, MUDI Mesra samalanga mendirikan STAI, sebagai lanjutan dari Dayah salafiyah.

\section{DAFTAR PUSTAKA}

Dhofir, Zamaksyari. 1984. Tradisi Pesantren, Studi tentang Pandangan Hidup Kiyai, Jakarta: LP3ES.

Gibb, H.A.R. dan Kramers, 1961. Shorter Encyclopedia of Islam. Leiden: E.J.Brill. Haspy, Tgk. Mohd Basyah. 1987. Apresiasi terhadap Tradisi Dayah: Suatu Tinjauan Terhadap Tata Krama dan Kehidupan Dayah. Banda Aceh: Panitia Seminar Appresiasi Pesantren di Aceh, Persatuan Dayah Inshafuddin.

Hurgronje, C. Snouck. 1906. The Atjehnese, A.W.S.O'Sullivan (terj), Vol.I, Leiden: E.J.Brill.

Ismail, Badruzzaman dkk (ed), 2002. Perkembangan Pendiidkan di Nanggroe Aceh Darussalami. Banda aceh:Majlis Pendidikan Daerah Aceh.

Qomar, Mujamil. 2006. Pesantren dari Transformasi Metodologi Menuju Demokratisasi Institusi. Jakarta: Erlangga.

Sufi, Rusdi dan Agus Budi Wibowo, 2009. Pendidikan di Aceh dari Masa ke Masa. Banda Aceh: Badan Arsip dan Perpustakaan NAD.

Sulaiman, M. Isa. 1997. Sejarah Aceh. Jakarta: Pustaka Sinar Harapan, Ziemek, Manfred. 1986. Pesantren dalam Perubahan Sosial. Jakarta: P3M,. 